\title{
São Paulo State e-gov: LabIHC and e-Poupatempo's Experience
}

\author{
Renato Facis, Carlos Alberto Neves Torres, and Jair Barreto de Vasconcelos \\ PRODESP - Information Technology Company of São Paulo State \\ Agueda Gonçalves Street, 240 - Taboão da Serra, São Paulo, Brasil \\ \{rfacis, ctorres, jvasconcelos\}@sp.gov.br \\ http: / /www.prodesp.sp.gov.br/labihc \\ http://www.poupatempo.sp.gov.br/e_poupatempo/index.htm
}

\begin{abstract}
This document describes the experience of São Paulo state government in its initiatives to develop an e-gov standard, focusing on the importance of centralization of access efforts from the citizen's perspective and the role of human-computer interaction and social and digital inclusion in this process.
\end{abstract}

Keywords: Electronic government (e-gov), social inclusion, digital inclusion, human-computer interaction (HCI), usability, accessibility.

As technology advances and e-gov guidelines develop fast, São Paulo state departments are more and more offering their services on the Web. Under this scenario in 2002 the São Paulo state government - through Casa Civil Strategic Information System Coordination and Prodesp's Poupatempo Superintendence identified the need to transfer to the web the citizen services standards previously only provided at Poupatempo Service Centers in a face-to-face mode. The aim was to reach excellence levels for digital environmental.

Hence "e-poupatempo" was born with the mission to guarantee the citizen's access to public e-services and to propose continuous service improvements based on such demand. Along the lines of social and digital inclusion, service rooms were provided where the citizens, supported by staff, could access e-services such as police incident registration, vehicle license plate registration query and payment, issuance of water / energy / telephone bills in case original ones are not available, among others.

These rooms also function as observatories of service usage and population profile. All occurrences are registered on-line and the usage variables are collected, adding up to 1.5 million occurrences since 2002. Some variables such as service identification, interaction duration and request for help are always collected, while specific campaigns are developed to identify more particular interaction obstacles, such as problems in text interpretation, font size, colors, filling up of certain forms, and so on.

"LabIHC" (Laboratory for Human-Computer Interaction) was created in 2003 to assess usability and accessibility of government sites, providing information to continuously improve government web site services, always focusing on the citizen. In this laboratory real tests are performed with the public service users; humancomputer interface problems are hence identified based on usability and accessibility 
heuristics. The results are supplied to the governmental entities responsible for the web sites. Till this date the LabIHC results were:

- 23 web sites/electronic public services reviewed

- $50 \%$ of the occurrences identified were corrected by the responsible entities, even though they were not mandatory or punitive.

LabIHC also takes advantage of direct interface of the e-room with the citizen to do research and collect data about the web site usage. In 2004 a survey with more than 150.000 samples was prepared of the social and demographic profile and the difficulties faced by the citizen in his interaction with public web sites. The outcome was the development of the typical São Paulo state e-gov user profiles. Along the line of citizen focus, research correlating citizen expectations and preferences regarding the São Paulo e-gov was developed to guide subsequent initiatives. A concrete example of a problem identified through the e-poupatempo rooms was the difficulty citizens faced when filling out an electronic police registration form. In most cases the activity could not by completed without staff support. Based on this fact a detailed inspection was carried out by LabIHC with real citizen experiments and the registration form was revised subsequent to collaboration with Public Safety Department.

A set of rules and web interface standards were created based on the accumulated experience in order to standardize and guarantee the quality of the São Paulo state egov in its interaction with the citizen. Six manuals were issued via CC-9 resolution of the São Paulo state Casa Civil and are available to all governmental web developers.

Regarding accessibility, LabIHC also did qualitative research to learn about the egov expectations and demands from the special needs citizens, supporting initiatives in that direction.

E-poupatempo and LabIHC established successful partnerships with private companies. Intel sponsored LabIHC and Guarulhos e-poupatempo service room. Similarly AMD sponsored the e-poupatempo service room in Itaquera, São Paulo, making evident the interest of the private sector in technology and digital inclusion projects, as well as the governmental capability to execute these partnerships in a clear form at low cost and with good results.

Academic alliances are also remarkable in the history of LabIHC. LTS (Software Technology Laboratory from Polytechnic School - USP supported the installation of LabIHC and handed over the full methodology on usability, accessibility and HCI used in the tests since 2003.

In worldwide terms, e-poupatempo is part of the e-goia project (part of @LIS program - Alliance for Information Society), a cooperation initiative to accelerate the development of e-gov in Latin America and to strengthen the partnerships with European Community and the Latin American governments. In this project an integration database solution prototype was built - if an ID is stolen, for example, the citizen can register his loss on line and is promptly offered to get a new ID (by filling out his current data) and advised of the ID pick-up schedule at a Poupatempo address. At the same time the old document is cancelled.

As a consequence of this project, Inlets (International Laboratories Network for egov Services and Technology) was created to provide knowledge and expertise exchange among e-gov laboratories. LabIHC is one of the Brazilian participants in this initiative that gathers laboratories from 5 Europe and South American countries. 